\title{
GEOLOGICAL SETTINGS AND SEISMIC ATTRIBUTES IN ALBIAN CARBONATES RESERVOIRS - SOUTHWEST OF CAMPOS BASIN (RJ - BRAZIL)
}

\author{
Luana Fernandes do Nascimento ${ }^{1}$, Maria Gabriela Castillo Vincentelli² \\ and José Alexandre de Jesus Perinotto ${ }^{3}$
}

\begin{abstract}
The importance of carbonates reservoirs in the global oil stage justifies studies aimed to determine the distribution of their physical properties. Moreover, as these reservoirs are considered complex in a geophysical context, it is necessary to reduce the geological uncertainty related to the main reservoir facies distribution. Based on this previous issue, this work outlines a method of obtaining pseudo-physical properties such as porosity $(\phi)$ and density $(\rho)$ of two carbonate reservoirs using quantitative analysis of seismic attribute maps. These intervals were delimited by a structural-stratigraphic trap (faults and lateral variation of carbonate facies) at the Albian level from the Southwest of Campos Basin, where an oil producer field is located in a structural high. The reservoirs are of good quality, with an average porosity of $20 \%$, directly calculated from well logs (mainly NPhi). This property features a high variation throughout the field, justified by the heterogeneity of the carbonate rock. Qualitatively, the reservoir distribution was obtained from the integration of structural, isoproperties and seismic attribute maps, which were applied above each reservoir surface maps; among them, the Maximum Negative Amplitude, Maximum Absolute Amplitude and Minimum Amplitude showed a linear relation at the correlation crossplot of density and porosity $\left(R^{2}>0.74\right)$. So, such process showed to be successful in characterization of the mentioned properties.
\end{abstract}

Keywords: porosity, seismic interpretation, carbonates physical properties, well correlation.

RESUMO. A importância dos reservatórios carbonáticos no cenário petrolífero mundial justifica estudos que objetivam determinar a distribuição de suas propriedades físicas. Além disso, como estes reservatórios são considerados complexos de serem caracterizados no âmbito geofísico, é necessário diminuir a incerteza geológica associada à distribuição das principais fácies reservatórios. Com base neste contexto, este trabalho apresenta um método de obtenção de pseudopropriedade, como porosidade $(\phi)$ e densidade $(\rho)$, de dois reservatórios carbonáticos com base em análise quantitativa de mapas de atributos sísmicos. Estes intervalos foram delimitados por uma trapa estrutural-estratigráfica (falhas e variação lateral de fácies carbonáticas) no nível Albiano do sudoeste da Bacia de Campos, onde um campo produtor de hidrocarbonetos está situado sobre um alto estrutural. Nesta região, os reservatórios são de boa qualidade com porosidade média de 20\%, calculada diretamente de perfis de poços (NPhi). Esta propriedade apresenta alta variação ao longo do campo, justificada pela heterogeneidade da rocha carbonática. Qualitativamente, a distribuição do reservatório foi obtida pela integração de mapas estruturais, de isopropriedades e de atributos sísmicos, os quais foram calculados nos mapas de cada reservatório; entre eles, Máxima Amplitude Negativa, Máxima Amplitude Absoluta e Mínima Amplitude apresentaram uma relação linear nos gráficos de correlação com a densidade e porosidade (coeficiente $R^{2}>0,74$ ). Assim, esse processo se mostrou eficaz na caracterização das propriedades mencionadas.

Palavras-chave: porosidade, interpretação sísmica, propriedades físicas dos carbonatos, correlação de poços.

\footnotetext{
1 Universidade Estadual Paulista "Júlio de Mesquita Filho" (UNESP), Pós-Graduação em Geociências e Meio Ambiente, Centro de Geociências Aplicadas ao Petróleo (UNESPETRO), Instituto de Geociências e Ciências Exatas (IGCE), Avenida 24-A, 1515, Bela Vista, 13506-900 Rio Claro, SP, Brasil. Phone: +55(19) 3526-9473 E-mail: luanaf_n@yahoo.com.br

2Universidade Estadual Paulista "Júlio de Mesquita Filho" (UNESP), Fundação para o Desenvolvimento da Unesp (FUNDUNESP), Laboratório de Interpretação de dados sísmicos e geológicos (LISG), Centro de Geociências Aplicadas ao Petróleo (UNESPetro), Avenida 24-A, 1515, Bela Vista, 13506-900 Rio Claro,SP, Brazil. Phone: +55(19) 3526-9475 - E-mail: g_vicentelli@yahoo.es 3 Universidade Estadual Paulista “Júlio de Mesquita Filho" (UNESP), Instituto de Geociências e Ciências Exatas, Avenida 24-A, 1515, Bela Vista, $13506-900$ Rio Claro, SP, Brazil. Phone: +55(19) 3526-9004 - E-mail: perinoto@rc.unesp.br
} 


\section{INTRODUCTION}

The actual characterization of reservoir porosity and its distribution is important because it influences the production strategy and the VOIP (volume of oil in place) calculus for any identified prospect, which can define its viability.

However, for carbonate reservoirs, this property could be highly variable in vertical and lateral directions. Therefore, as the porosity can vary in a centimeter scale, it is considered that its characterization would be a challenge in terms of defining it using geophysical data.

In this context, this paper aims to determine the distribution of carbonate reservoir properties by analyzing seismic attributes maps in the main identified reservoirs levels of Quissamã Formation (Albian age) in the Southwest of the Campos Basin.

This analysis starts in a qualitative way considering the geological data stated by previous petrophysical and structural studies of the area (geological settings). Based on these results, this work adds the quantification of the association between the seismic attributes and the rock property measured in geophysical well logs by means of correlation graphs. In this sense, the same properties distribution was verified at isoproperties and isopach maps.

This geophysical-geological integration is extremely important because it emphasizes the variation of the physical property of the rock that directly influences the production of the reservoir. Although the geological facies model suggests regions of possible high porosity values, the geological uncertainty for the areas that have not been drilled is still considered high. So, the seismic attribute analysis helps to reduce the risk related to the distribution of interest areas even in the regions with no well data.

These tools should be used because the seismic data covers a bigger area than the wells, and according to the established relation between the rock and seismic amplitude, it is possible to extrapolate the interpretation of local information. In the reservoirs levels, a pattern of seismic amplitude response associated to density and velocity changes can be stated. So, among all calculus in different approaches (sum of positive/negative/absolute amplitudes, mean amplitude and maximum/minimum amplitude, etc.), the crossplots (quantitative) and maps (qualitative) should direct the better representation of the study reservoirs.

Apart from that, it is important to emphasize that despite the studied Albian level is considered a mature area, this interval still contains oil potential that could be reevaluated and/or discovered at this or another basins with similar geological plays. Therefore, this methodology could be useful in the characterization of possible targets based on seismic interpretation and rock property distribution even in fields that have been producing for many years.

\section{GEOLOGICAL SETTINGS}

The study area is a hydrocarbon field located in the Southwest of Campos Basin, in the continental shelf of Rio de Janeiro state, $80 \mathrm{~km}$ away from the shoreline, and average water depth of 95 to 125 meters (Horschutz et al., 1992) (Fig. 1).

The geological evolution of Campos Basin is associated to the separation of the South American and African plates during the Lower Cretaceous. Its tectonic evolution comprises three mains phases: rift, pos-rift and drift, in which the continental, transitional and marine sequences were deposited respectively (Dias et al., 1990; Winter et al., 2007).

The Albian carbonates of Macaé Group (drift phase) are composed in the study area by the Quissamã and Outeiro Formations deposited above the evaporites layer (transitional sequence).

The Quissamã Formation consists predominantly of grainstones and packstones that were deposited on a shallow carbonate platform (Spadini, 1986; Esteves et al., 1987). These facies represent the main oil producer reservoirs at this stratigraphic level. Subsequently, with the drowning of this platform, essentially wackestones, mudstones and marls formed the Outeiro Formation.

According to the depositional model of Guardado et al. (1989) for the Quissamã Formation, carbonate banks were deposited parallel to the shoreline in NE-SW direction. In a detail of this model for the study area, Okubo (2014) described 11 facies grouped in 5 facies associations, which the high energy facies would be arranged in the ridges of the carbonate banks, while the low energy facies would be on the flanks.

In the study area, the reservoirs levels denominated R1 and R2 (Nascimento, 2016) have mainly oncolytic packestone and grainstone facies that indicates high and moderate energy environment according to Okubo et al. (2015) (Fig. 2).

\section{MATERIALS AND METHODS}

This work used geophysical data provided by the Agência Nacional do Petróleo, Gás Natural e Biocombustíveis (ANP Petroleum National Agency), composed by 20 wells (depth sampled in meters) and one seismic cube of $50 \mathrm{~km}^{2}$ (time domain) (Fig. 3). The wells contain information of five geophysical well logs (in .las format): Gamma Ray (GR), Resistivity (ILD), Sonic (DT), Density (RHOB) and Neutron Porosity (NPhi).

The stratigraphic intervals defined in the study area were delimited according to the changes of the well logs mode. Four main stratigraphic intervals were interpreted: Outeiro Formation, Q1 (transition between Quissamã and Outeiro Formation) and the main reservoirs R1 and R2 that are the focus of this paper. They 


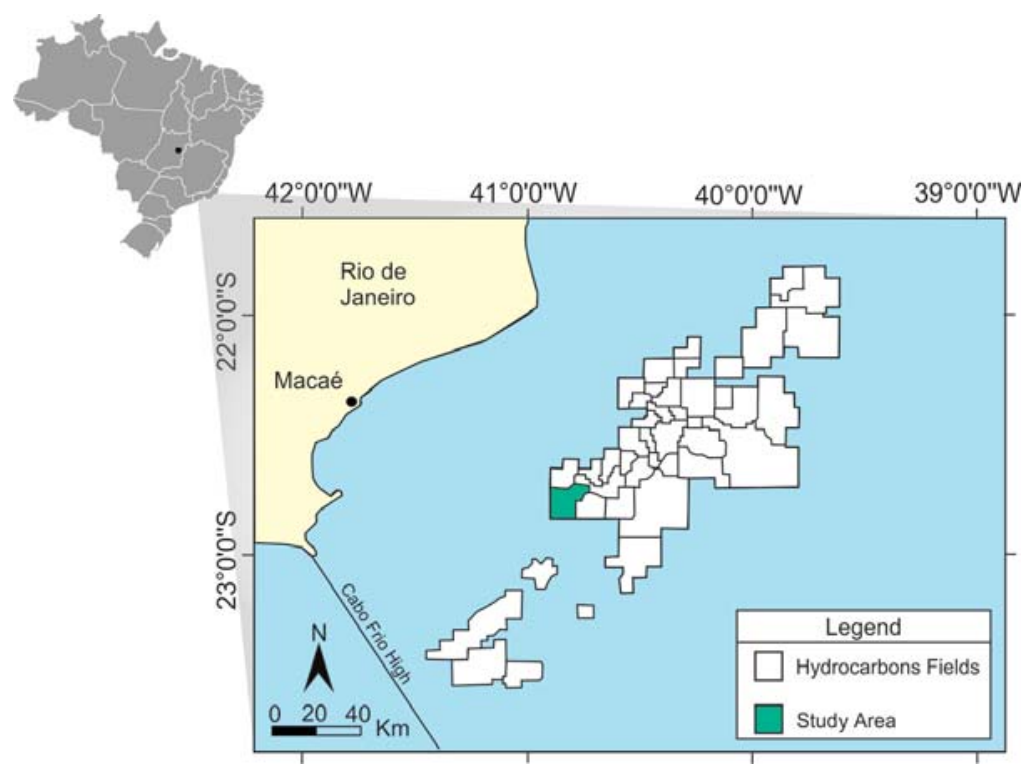

Figure 1 - Location of the study area.

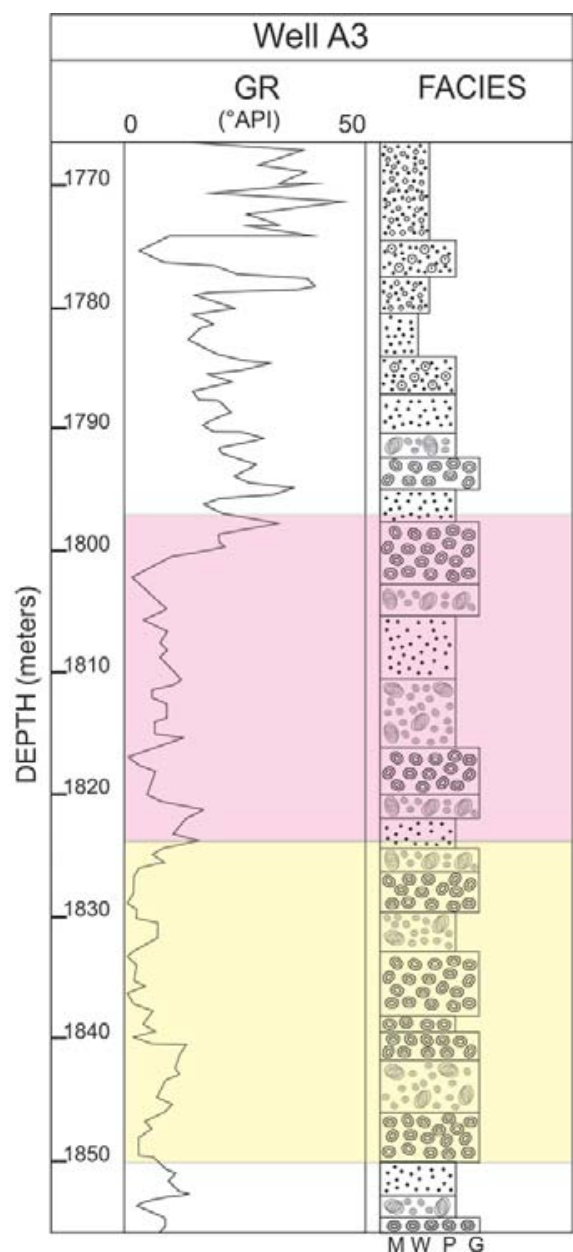

\begin{tabular}{|c|}
\hline LEGEND \\
\hline $\begin{array}{l}\odot \text { ooids } \\
\text { oncoids } \\
\text { aggregate grains } \\
\approx \text { peloids }\end{array}$ \\
\hline $\begin{array}{l}\text { M mudstone } \\
\text { W wackestone } \\
\text { P packstone } \\
\text { G grainstone }\end{array}$ \\
\hline GR - Gamma ray \\
\hline $\begin{array}{l}\text { Macaé Group } \\
\text { Quissamā Formation }\end{array}$ \\
\hline Reservoir R1 \\
\hline Reservoir R2 \\
\hline
\end{tabular}

Figure 2 - Well A3 with the facies and reservoirs R1 and R2 (Okubo et al., 2015; Nascimento, 2016). 
were interpreted on well logs and correlated along the study field in order to verify their continuity and lateral variation.

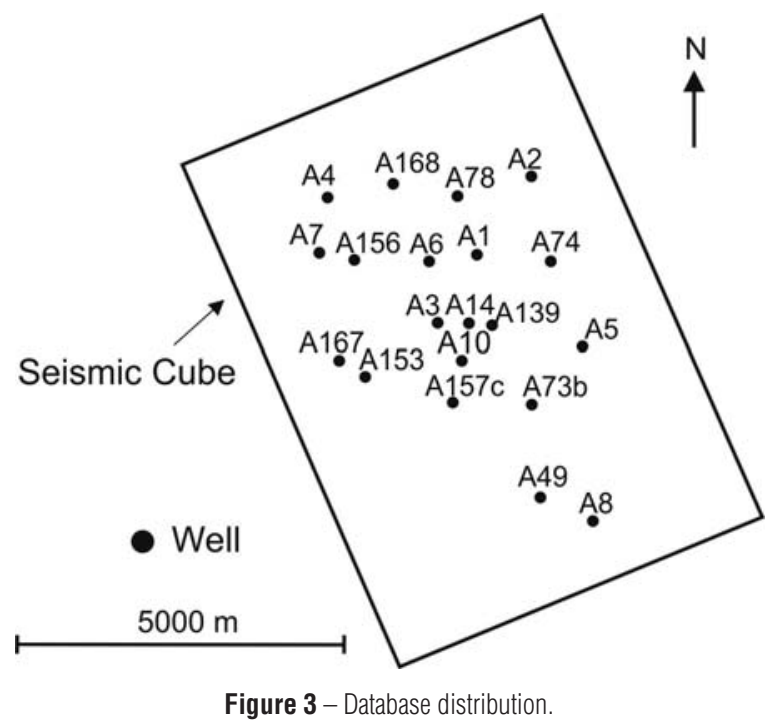

The used method consisted of 3 main steps:

\section{Definition of main reservoirs levels based on well logs and correlation}

The wells $\mathrm{A} 3$ and $\mathrm{A} 10$ were considered references because they are recognized as main oil producer wells for this hydrocarbon field (Fig. 4).

In order to represent the distribution tendencies of density and porosity properties of the study reservoirs, the mode values were measured in the well logs (RHOB and NPhi). The mode is the most sampled value in the analyzed reservoirs that present unimodal distribution (Fig. 5). Then, the values were interpolated using Minimum Curvature method that was considered the better option that does not add false tendencies for the available number of wells.

\section{Definition of the structural model using seismic interpretation}

The seismic (time domain) was calibrated with the wells (depth domain) using synthetic seismograms created in Decision Space software with the density and sonic logs (Fig. 6). It was also used the dominant frequency of the seismic data (Ricker $-33 \mathrm{~Hz}$ ). Then, the stratigraphic horizons that correspond to the levels R1 and R2 tops were interpreted.

The R1 top is in a peak of negative amplitude as expected for an oil producer reservoir in normal seismic polarity. The reservoir R2 is expected to be at Minimum Amplitude as well, but it is in a zero-crossing justified by the low resolution of the seismic considering the reservoir thickness.

Also, the main faults were interpreted because of their high influence on the delimitation of these study reservoirs. As a result, structural maps were obtained and used in the next step to calculate the seismic attributes.

\section{Pseudo-porosity maps based on seismic attributes analysis}

On the R1 and R2 surface maps, 14 seismic attributes were calculated: RMS Amplitude, Mean Amplitude, Mean Absolute Amplitude, Maximum Positive Amplitude, Maximum Negative Amplitude, Maximum Absolute Amplitude, Maximum Amplitude, Minimum Amplitude, Sum of Positive Amplitudes, Sum of Negative Amplitudes, Sum of Absolute Amplitudes, Trace Power, Total Energy and Maximum Peak Amplitude; and one volumetric attribute: Sweetness (options available in Decision Space software).

According to Vincentelli et al. (2014), Sweetness is an empirical reservoir visualization method that highlights the carbonate reservoir based on the difference between siliciclastic and carbonates which generates high acoustic impedance contrast. It is defined mathematically by the ratio between envelope and the root square of the instantaneous frequency (Eq. 1):

$$
\begin{aligned}
& \text { Equation } 1-\text { Volumetric attribute Sweetness } \\
& \text { Sweetness }=\frac{\text { Envelope }}{\sqrt{\text { Instantaneous Frequency }}}
\end{aligned}
$$

These attributes were calculated in the reservoir surfaces in a window (centralized) of 20 (R1) and 18 (R2) milliseconds, including the entire reservoir layer. These seismic attributes were extracted in order to verify if they respond to some reservoir property (porosity and density), initially in a qualitative way (identification of amplitude anomalies) and later, this relation was quantified by the construction of crossplots.

These graphs, as Figure 7 shows, are composed by the reservoir rock property value on the abscissa axis $(\mathrm{x})$ and the seismic attribute on the ordinate axis (y). In order to quantify the data dispersion, the correlation coefficient R2 was calculated.

The rock properties values were measured in the well logs at the reservoir intervals (mode), while the amplitude values were measured on the attribute map calculated in the same stratigraphic levels at the position of each well. 


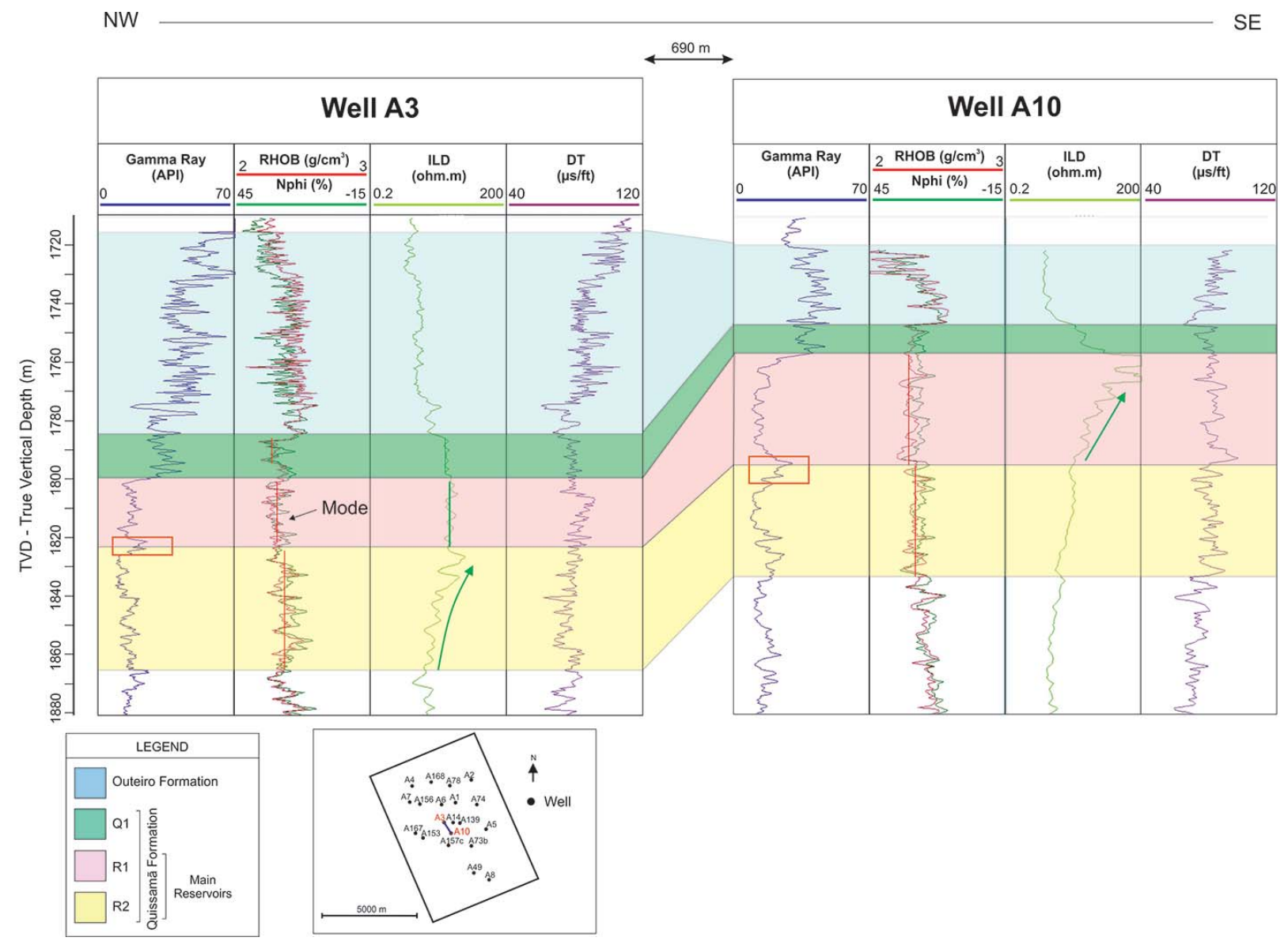

Figure 4 - Structural section between A3 and A10 wells. The red lines show the mode change in well logs. The orange square emphasizes the increase of the gamma ray log between the two reservoirs. The green line shows the resistivity that increases in different reservoirs for each well.
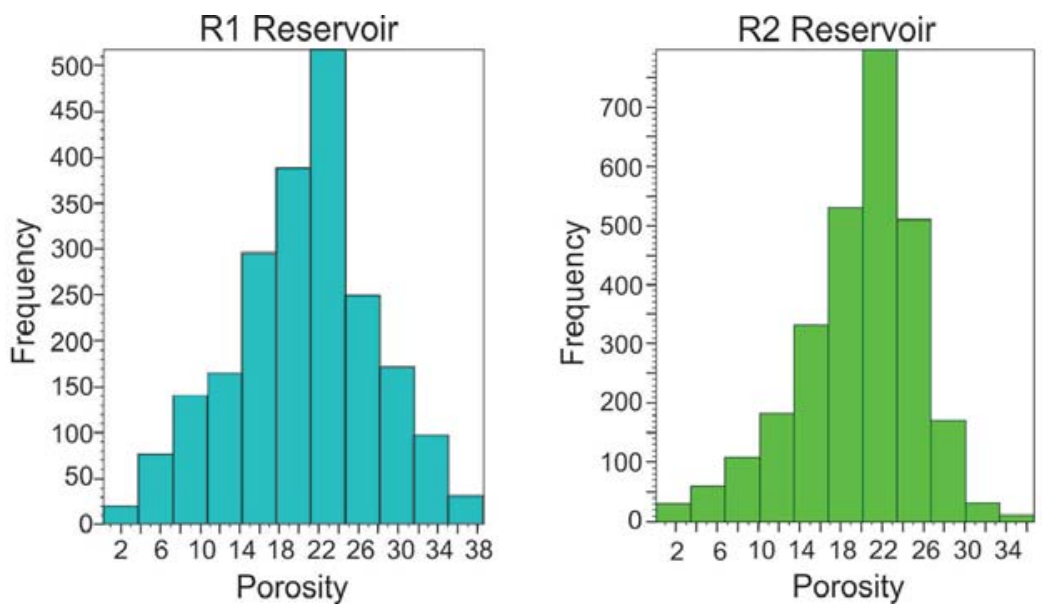

Figure 5 - Frequency histograms of the porosity in the reservoirs R1 and R2 presenting an unimodal distribution. The mode is $23 \%$ and $22 \%$ for $\mathrm{R} 1$ and $\mathrm{R} 2$ levels, respectively. 


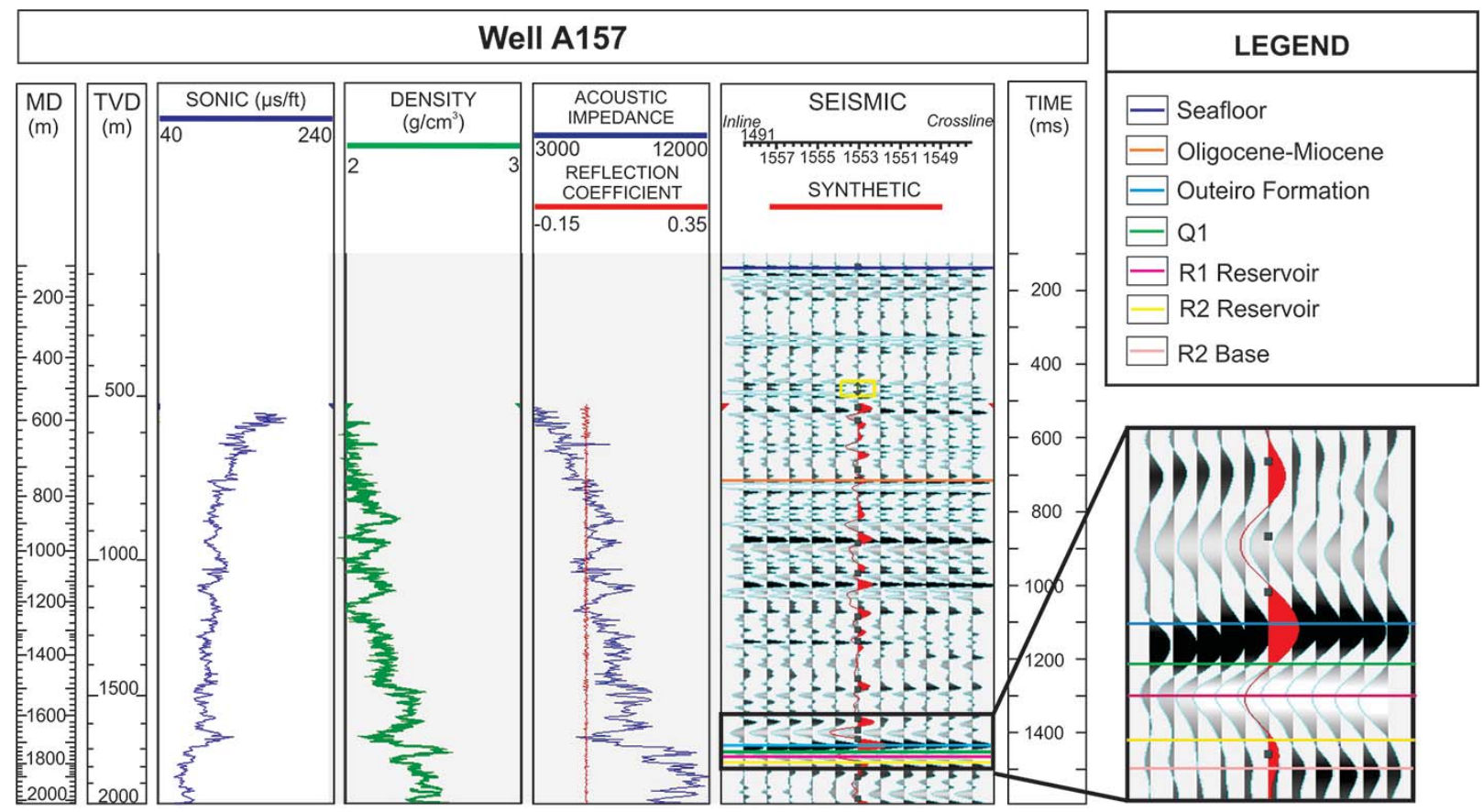

Figure 6 - Example of synthetic seismogram of well A157.

\section{Crossplot - Reservoir R1}

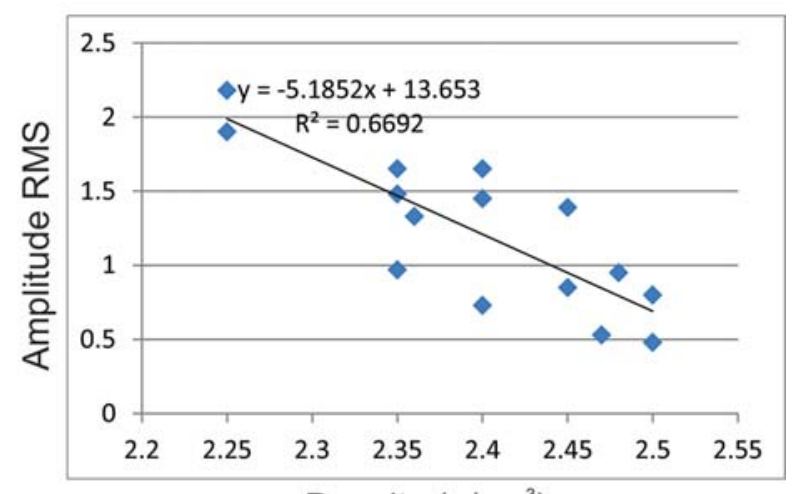

Density $\left(\mathrm{g} / \mathrm{cm}^{3}\right)$

Figure 7 - Correlation graph (crossplot) between the density values (RHOB) of the reservoir R1 and the RMS Amplitude seismic attribute.

\section{RESULTS}

\section{Analysis of well logs in reservoir levels}

The reservoir $\mathrm{R} 1$ is characterized in the study area by mean values of $30 \mathrm{~m}$ thickness, $20 \%$ porosity, $2.40 \mathrm{~g} / \mathrm{cm}^{3}$ density and water saturation of $30 \%$ (Nascimento, 2016).

By integrating the structural map (based on well data - in depth) of this level with the reservoir properties, it was observed that these mean values are divergent when located in the central structural high, because the wells A10, A3, A157, A139 and A14 exhibit porosity values greater than $20 \%$, while to the Northwest the porosity decreases to values less than $15 \%$ (Fig. 8).

The inverse situation was observed with the density distribution maps: the lowest values of this property (about $2.3 \mathrm{~g} / \mathrm{cm}^{3}$ ) are located in the central structural high and in the NE-SW trend.

The reservoir $\mathrm{R} 2$ shows a similar scenario: average values of $35 \mathrm{~m}$ of thickness, $15 \mathrm{API}$ degrees of gamma ray, porosity of $20 \%$, density of $2.43 \mathrm{~g} / \mathrm{cm}^{3}$ and water saturation of $30 \%$ (Nascimento, 2016). The highest values of porosity for this reservoir level are also in the central structural high.

The petrophysical properties variation of the carbonate facies suggests that the quality of both reservoirs (R1 and R2) is decreasing to the Northwest of the study area, because in this region the reservoir shows low porosity $(<16 \%)$, high density $\left(>2.55 \mathrm{~g} / \mathrm{cm}^{3}\right)$ and gamma ray higher than 30 API degrees (Nascimento, 2016) (Fig. 9).

In the well correlation, it is observed the higher structural position in the central area, where the reservoirs present high porosity ( $>20 \%$ ) and the resistivity log suggests hydrocarbon occurrence (Fig. 10).

In the correlation between A3 and A10 (Fig. 4 in Method), it was showed two different reservoir intervals that presented oil in different wells (R1 shows oil in A10 and R2 in A3). The well portfolios, resistivity and water saturation maps of the study area confirms that the mentioned structural high has major hydrocarbon reservoirs (Nascimento, 2016). 


\section{Maps of Reservoir R1}
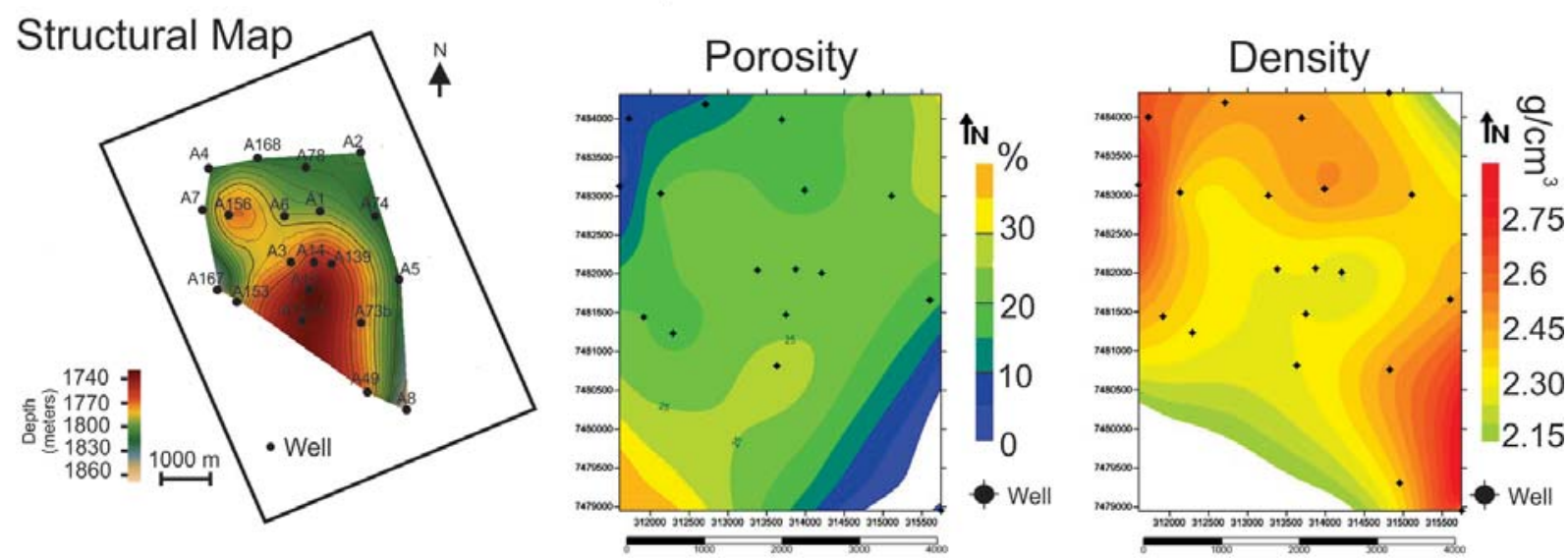

Figure 8 - Structural map based on well data and isoproperties maps of the reservoir R1. The high values of porosity (almost 25\%) and lowest values of density (until $2.35 \mathrm{~g} / \mathrm{cm}^{3}$ ) are in the central structural high. The central structural high is prominent in relation to adjacent areas and associated to high and moderate energy facies with good porosity and permeability, resulted in an area with a good condition for a reservoir.

\section{Maps of Reservoir R2}
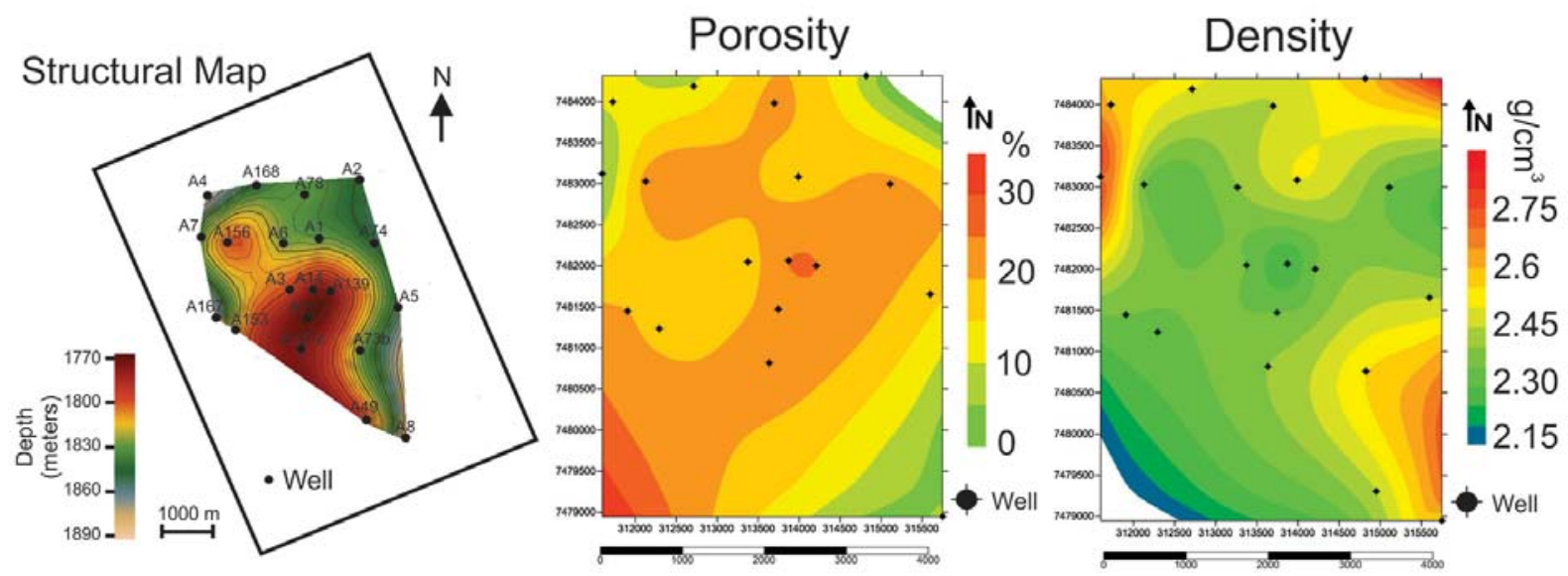

Figure 9 - Structural map based on well data and petrophysical maps of the reservoir R2. The high values of porosity and low values of density are distributed in the NE-SW trend.

\section{Structural model}

The stratigraphic horizons that correspond to R1 and R2 reservoirs were interpreted in time (ms) and then, they were converted in depth (meters) by using an interval velocity modeling. The interval velocities were obtained from the sonic logs and a normal ray incidence model was applied. In general, the velocity in the Albian carbonates shows mean values of $3900 \mathrm{~m} / \mathrm{s}$ while in the Neogene siliciclastic deposits reduces to $2400 \mathrm{~m} / \mathrm{s}$.

In the surface maps (R1 and R2 tops), a structural high with main axis Northwest-Southeast was observed. This structure is limited to the Northeast and Northwest by structural lows (flanks of the carbonate banks) that were filled later by the Campos Group (Upper Cretaceous to Quaternary) (Fig. 11).
In the Southeast region, the reservoirs are limited by the normal fault denominated Fa of N-S direction with great regional expression. The faults also deform all the Albian reservoirs in NWSE (faults Fd, e, f, g, h, I, j, k, n), N-S (faults Fa,b,c), E-W (faults $\mathrm{Fm}, 0$ ) and NE-SW (faults FI) directions. They isolate the reservoir from $\mathrm{A} 3$ and $\mathrm{A} 10$ wells from the ones that could exist in North and South of the main reservoir.

In the interpreted seismic sections, it was observed the postdepositional characteristic of the faults system that deform the reservoirs R1 and R2, which resulted in a similar structural configuration of these levels, as observed in the structural maps.

The seismic section shows that Fd can be interpreted as a listric fault and ends at the salt layer of Retiro Formation, gener- 


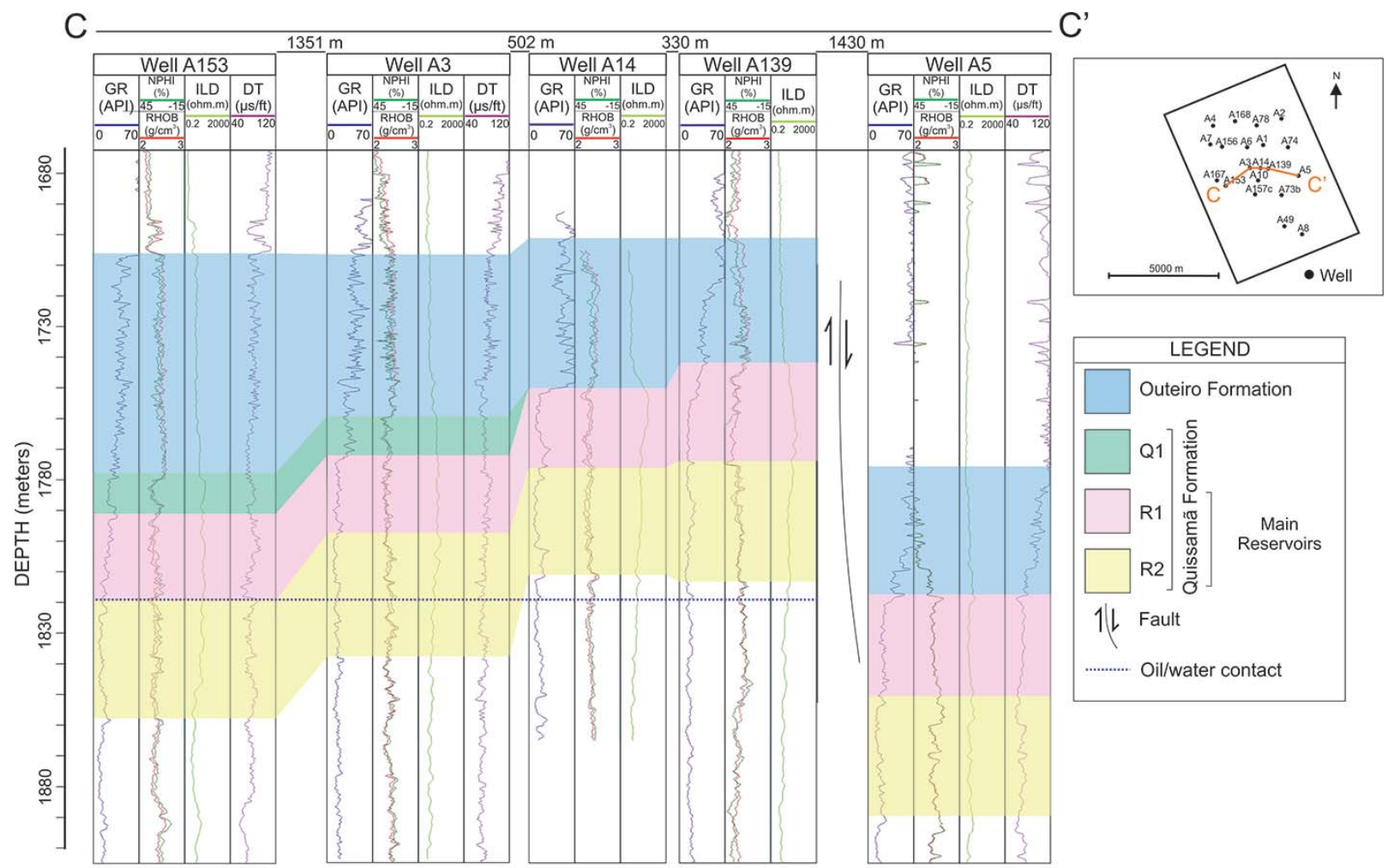

Figure 10 -Structural section E-W showing the lateral and vertical variation of reservoirs R1 and R2. The oil-water contact suggests that the well A5 is filled by water, also confirmed by the low values of resistivity log.
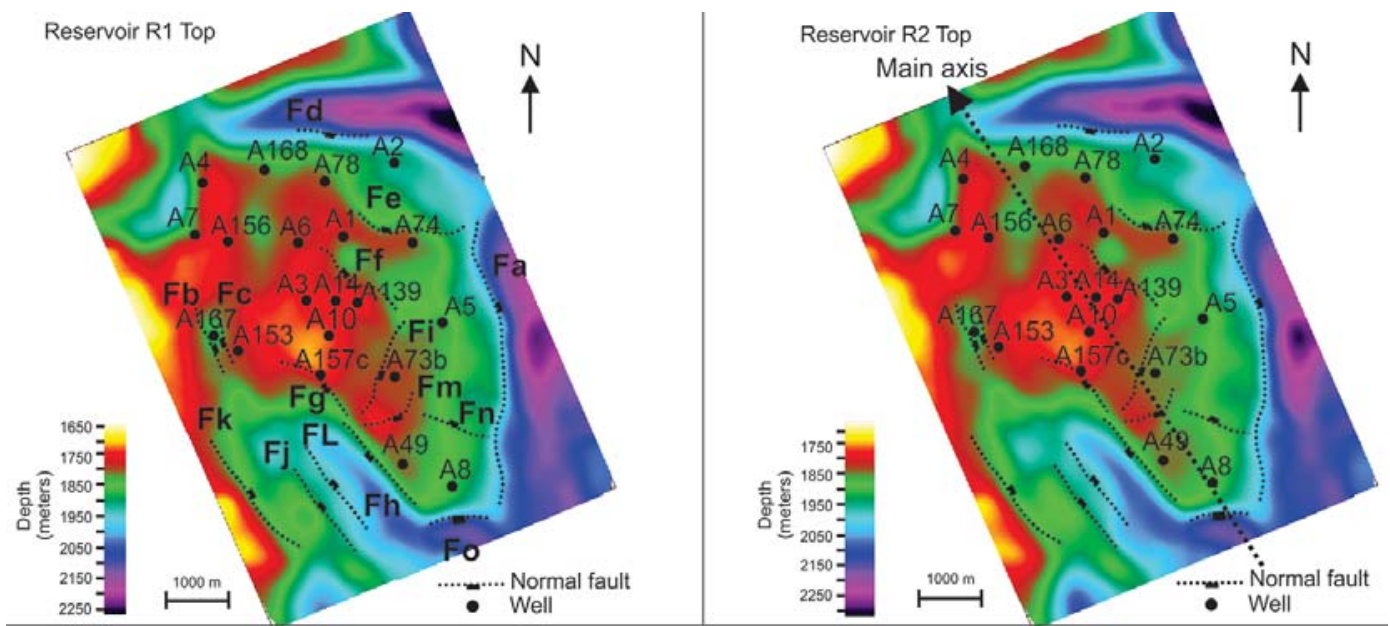

Figure 11 - Structural maps of the reservoirs R1 and R2 top.

ating a rollover structure where the wells A78 and A1 were drilled (Fig. 12).

The water depth in the study area shows low variation (until 30 meters), as well as the sedimentary layers. This data associated to the absence of high velocity layers above the reservoirs (salt, for example) result in a very similar scenario of the seismic in both scale (time and depth), that was confirmed after the conversion by interval velocity model application. So, despite the presented seismic section is in time (ms), the displayed structures are valid.

It is also possible to observe that the central structural high 


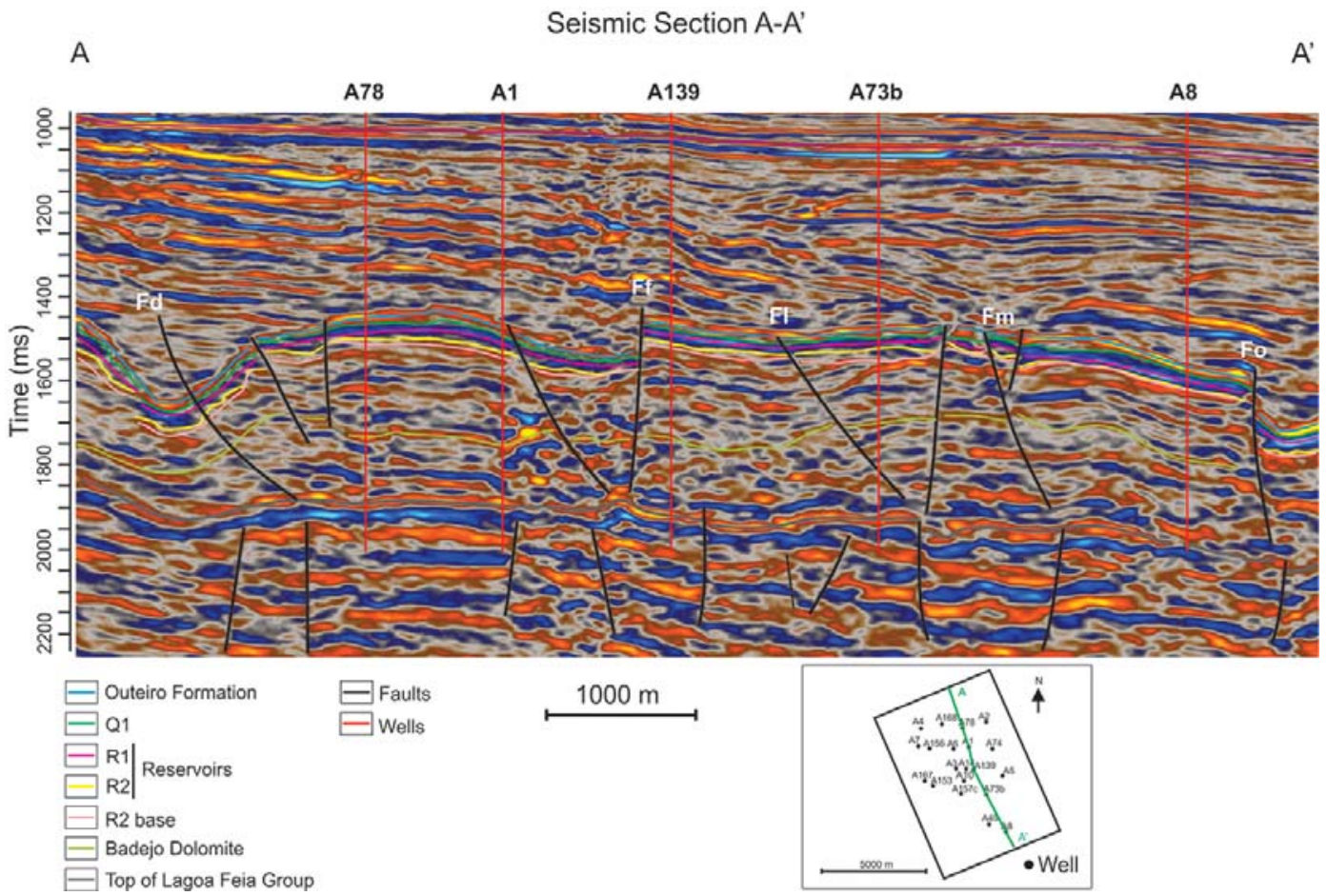

Figure 12 - Seismic section A-A'.

is limited by faults that separate it from the structural high to the south (well A8) and a rollover to the north (wells A78 and A1). At this central high there are the oil producer wells in the field (A3, A10, A139, A14 and A157). This structure is also limited by faults to the Southeast $(\mathrm{FI})$ and Southwest $(\mathrm{Fg})$, near the well A157.

The faults absence to the Northwest of the central structural high and also the tendency in the increase of rock density presented in the petrophysical maps (Figs. 8 and 9) show the limit of the reservoirs as stipulated by the lateral variation of carbonate facies, besides the structural factor. These characteristics classify the reservoirs R1 and R2 as delimited by a mixed trap.

The high influence of the faults in the central structural high was probably an important conditioning factor to become the area propitious for hydrocarbon accumulation, because it resulted in a structural position prominent in relation to the Southeast of the study area, associated to the presence of good quality carbonate facies (high porosity and permeability) as also interpreted by Bueno et al. (2014).

\section{Seismic Attribute Analysis}

Amplitude attribute maps were calculated for the reflections of reservoirs R1 and R2 tops and it was observed that the amplitude anomalies highlight the reservoir in the structural high near the A10 (central) and A8 (south) wells, and also in the Southeast, which differentiate these prominent areas from the rest of the carbonate bank (Fig. 13).

The seismic attribute maps that showed amplitude anomalies were correlated with values measured in the well logs of porosity and density. For the reservoir R1, there is a linear correlation among these properties with the seismic attributes Maximum Negative Amplitude, Maximum Absolute Amplitude and Minimum Amplitude with correlation coefficient of $R^{2}>0.74$; also RMS Amplitude and Total Energy with $R^{2}>0.65$, which quantifies the association between rock property and attribute value described above.

It can be observed in the Figure 14 that the main Albian oil producing wells (A3, A10, A157, A14, A139) are located in the central high of the area and they are associated to negative amplitude anomalies represented by green and blue colors in the map. The crossplots confirm that the lower values of density and higher porosity, characteristics of oil reservoir levels in the area, are associated with more negative values of the attribute, standing out from the rest of the area.

The map of Maximum Absolute Amplitude (Fig. 15) also presents amplitude anomaly with a similar shape to the previous map. In this figure, the crossplot shows lower values of density associated to higher values of Maximum Absolute Amplitude. 

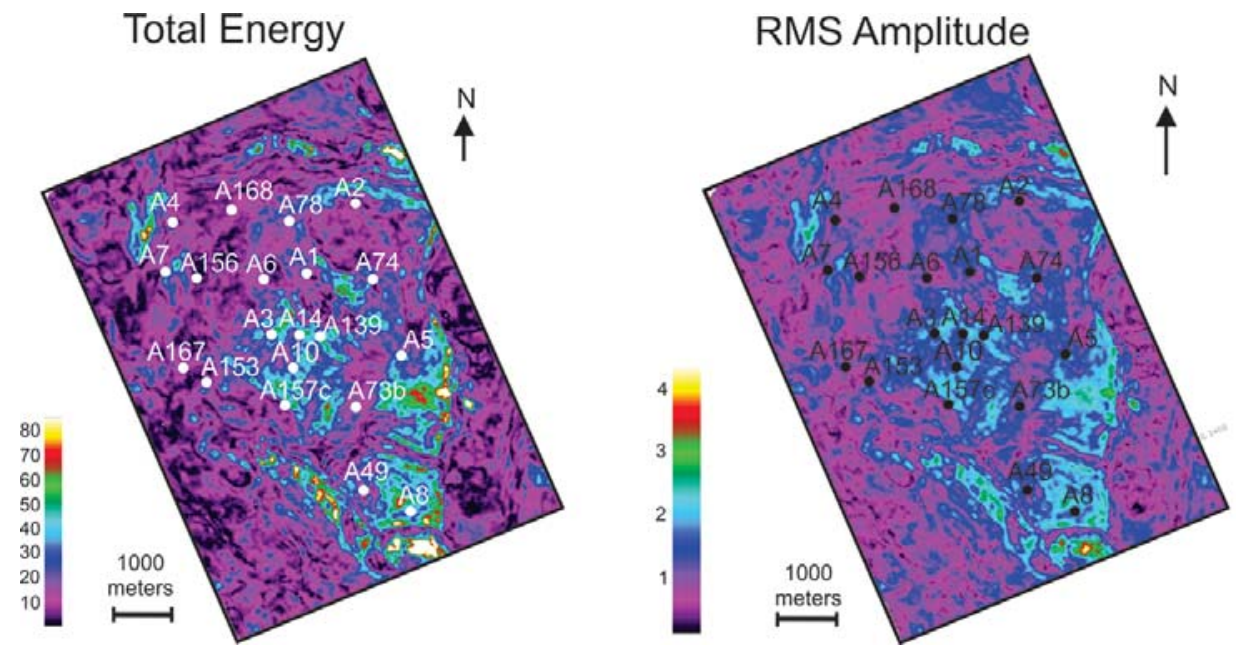

Figure 13 - Attribute map of Total Energy calculated in the reservoir R1 showing amplitude anomalies associated to the reservoir facies in the structural central high, and RMS Amplitude attribute presenting the same anomaly in green and blue. In a first analysis, the prior knowledge of isoproperties maps and facies description of Okubo et al. (2015) enabled to compare and to connect the position of central anomaly amplitude to porous and high permeability rock (good reservoir facies) in a qualitative way.

The main producer wells show density values between 2.25 and $2.4 \mathrm{~g} / \mathrm{cm}^{3}$ and they are highlighted in this map by the colors blue and green, which represent values of amplitude near 3 and 5 .

An amplitude anomaly also stands out at relatively lower structural positions compared to the central high such as Southeast of the well $A 5$, which suggests that reservoir facies are located in this region. This anomaly persists in the maps presented below and according to the correlation in crossplots, represents high porosity (or low density) of the rock in the stratigraphic level R1.

This region to the Southeast of the area was also interpreted by Bueno et al. (2014) as facies formed in high structural conditions and then, the block was moved down by post-depositional faults. As observed in well structural section (Fig. 10), the near well A5 should be filled by water, what suggests the interpretation that the porous rock in the Southeast has water as well. However, no well information is available in this area.

These amplitude anomalies are limited to the faults that cause displacement of adjacent blocks from the central high. The location of these faults justifies the fact that the anomaly is at the edge of wells A157 and A153, which by the analysis of their log, show high values of porosity in the reservoir levels.

With lower correlation index $\left(R^{2}=0.65\right)$, the reservoir $\mathrm{R} 1$ also showed similar amplitude anomalies in the attributes of RMS Amplitude and Total Energy (Nascimento, 2016).

For the reservoir R2 that shows hydrocarbon evidence in well
A3, the amplitude anomalies also represent the low density (and consequently high porosity) and the shape is similar to the presented maps of the level R1, following the same interpretation, but showing a greater dispersion of the data (Fig. 16). This could be related to the low resolution of seismic that sets the reservoir $\mathrm{R} 2$ near to a zero-crossing horizon. The reservoir R1 is in a strong negative amplitude peak and showed more accurate data in seismic properties.

The attributes that present a better correlation with the density and porosity of reservoir R2 are RMS Amplitude and Minimum Amplitude (Nascimento, 2016).

Based on the presented data, the seismic attributes tool was effective in the recognition of high porosity areas for reservoirs in Upper Quissamã Formation. In association with previous descriptions of carbonate facies, such as Okubo et al. (2015), it can be stated that these facies also contain high permeability and, therefore, they are considered as high quality reservoirs facies.

Considering the relation of amplitude anomalies with the high porosity facies and reservoir quality, it is observed that their occurrence in the study area is concentrated in the central structural high, at the Southeast and at the South, absent in the fault planes and in the extremes structural lows (Northwest and Northeast).

By using the opacity and transparency tool in the Sweetness attribute, the pseudo-porosity map of the study area can be obtained by highlighting only the main facies: high porosity (16 to 28\%), as shown in the Figure 17. 
Maximum Negative Amplitude

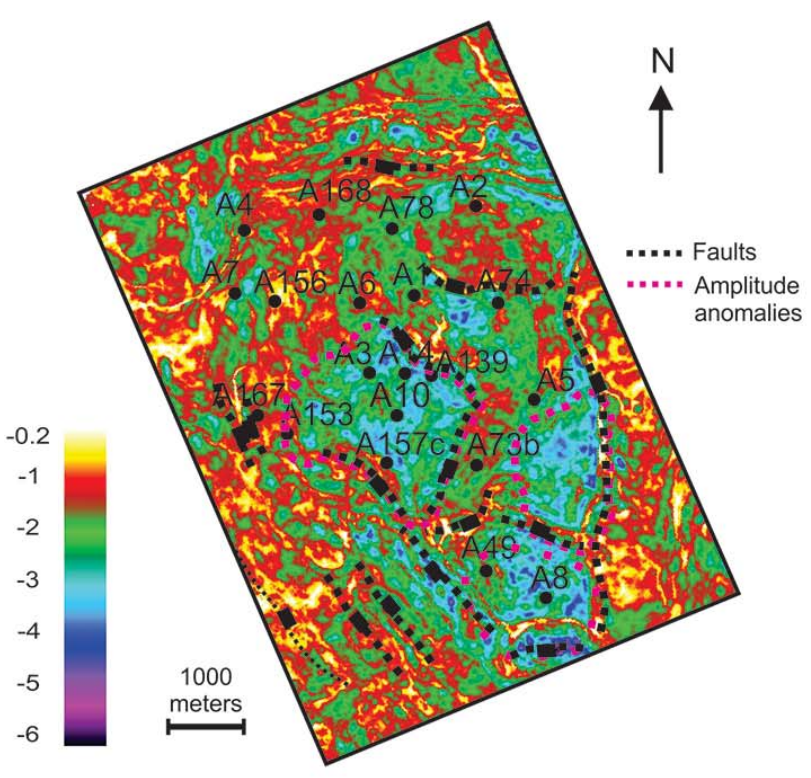

Density $\left(\mathrm{g} / \mathrm{cm}^{3}\right)$
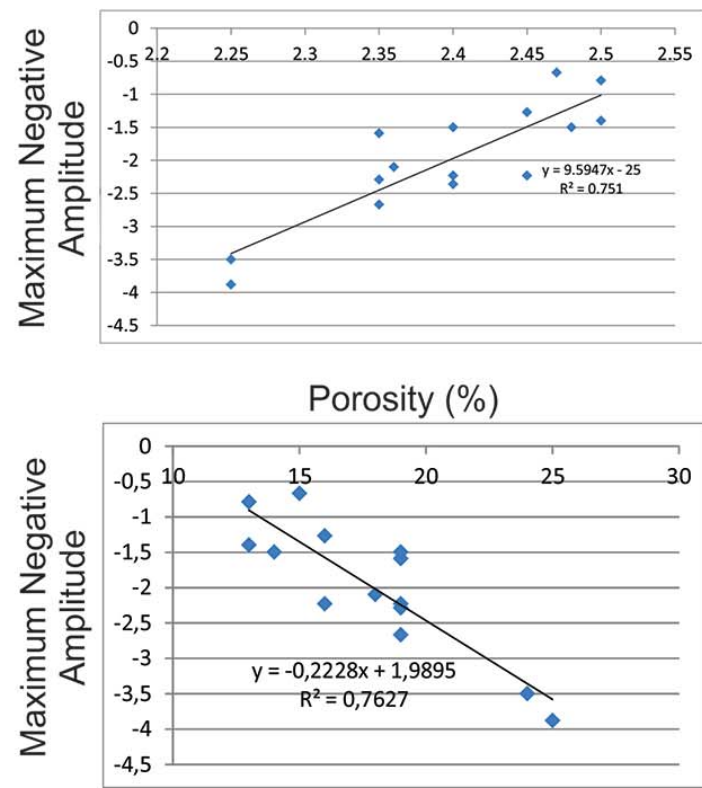

Figure 14 - Maximum Negative Amplitude attribute applied on reservoir R1 top and crossplots between the attribute value and the density/porosity properties.

\section{Maximum Absolute Amplitude}

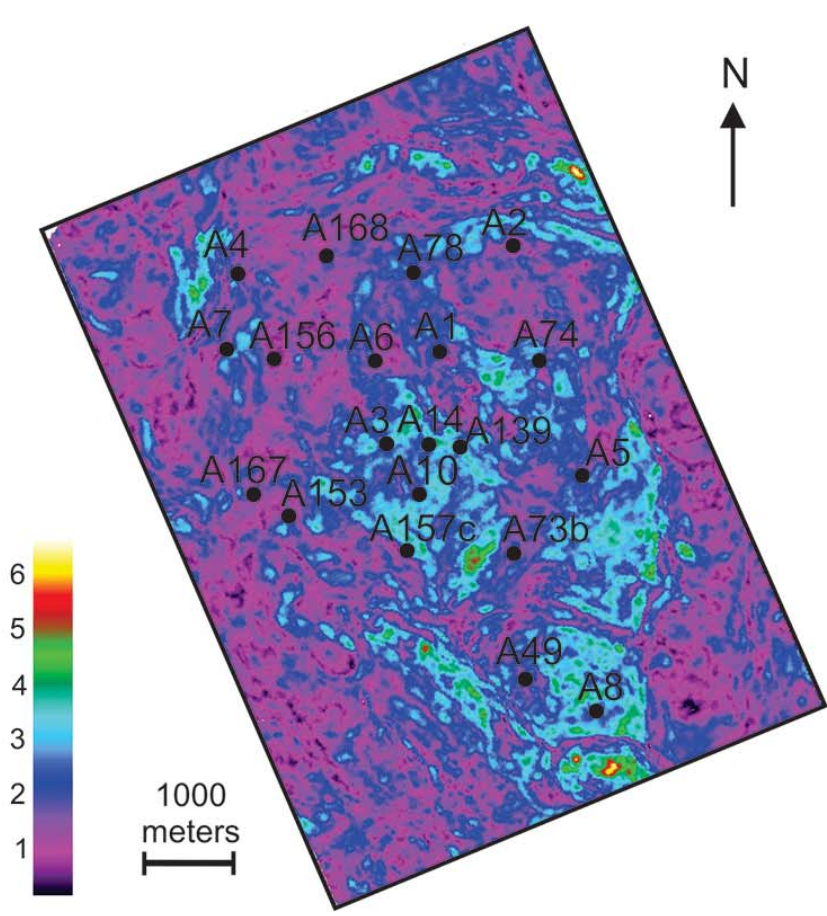

Density $\left(\mathrm{g} / \mathrm{cm}^{3}\right)$
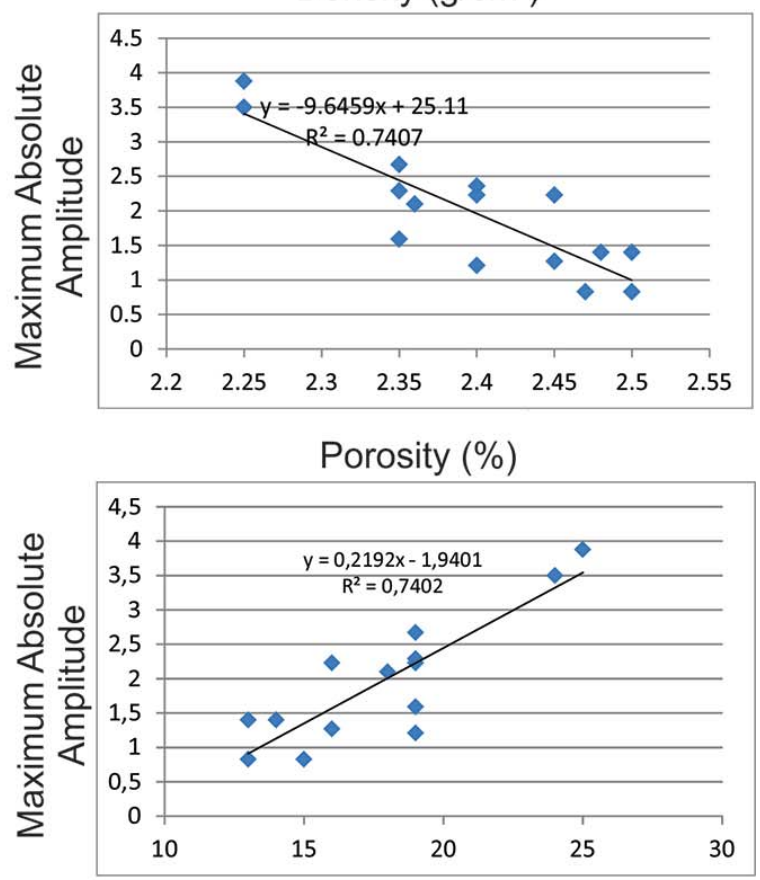

Figure 15 - Maximum Absolute Amplitude attribute applied on reservoir R1 top and crossplots between the attribute value and the density/porosity properties. 


\section{Minimum Amplitude}

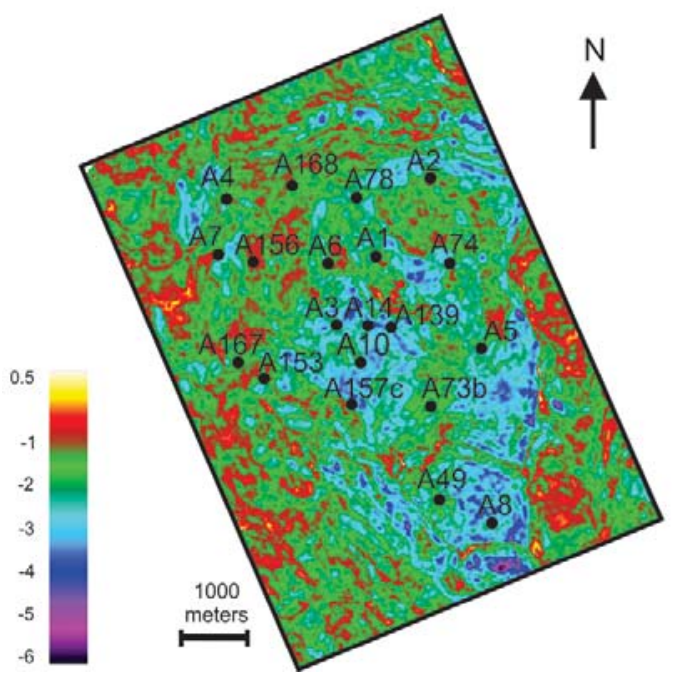

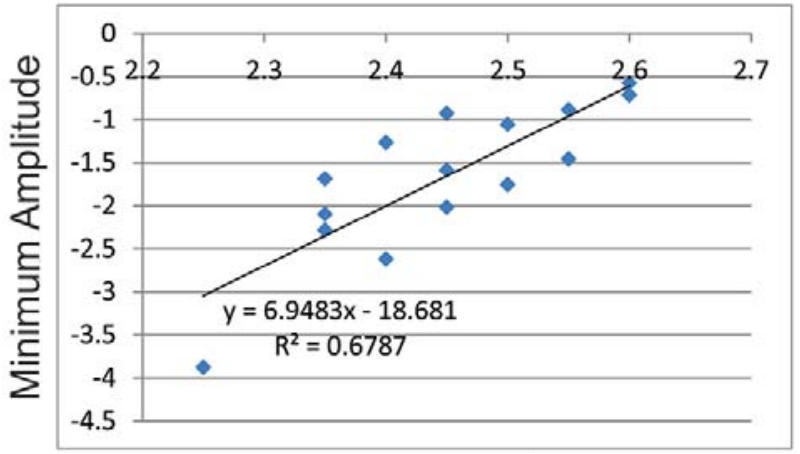

$\mathrm{RHOB}\left(\mathrm{g} / \mathrm{cm}^{3}\right)$

Figure 16 - Minimum Amplitude calculated in the reservoir R2 top and crossplots between the attribute values and density property.

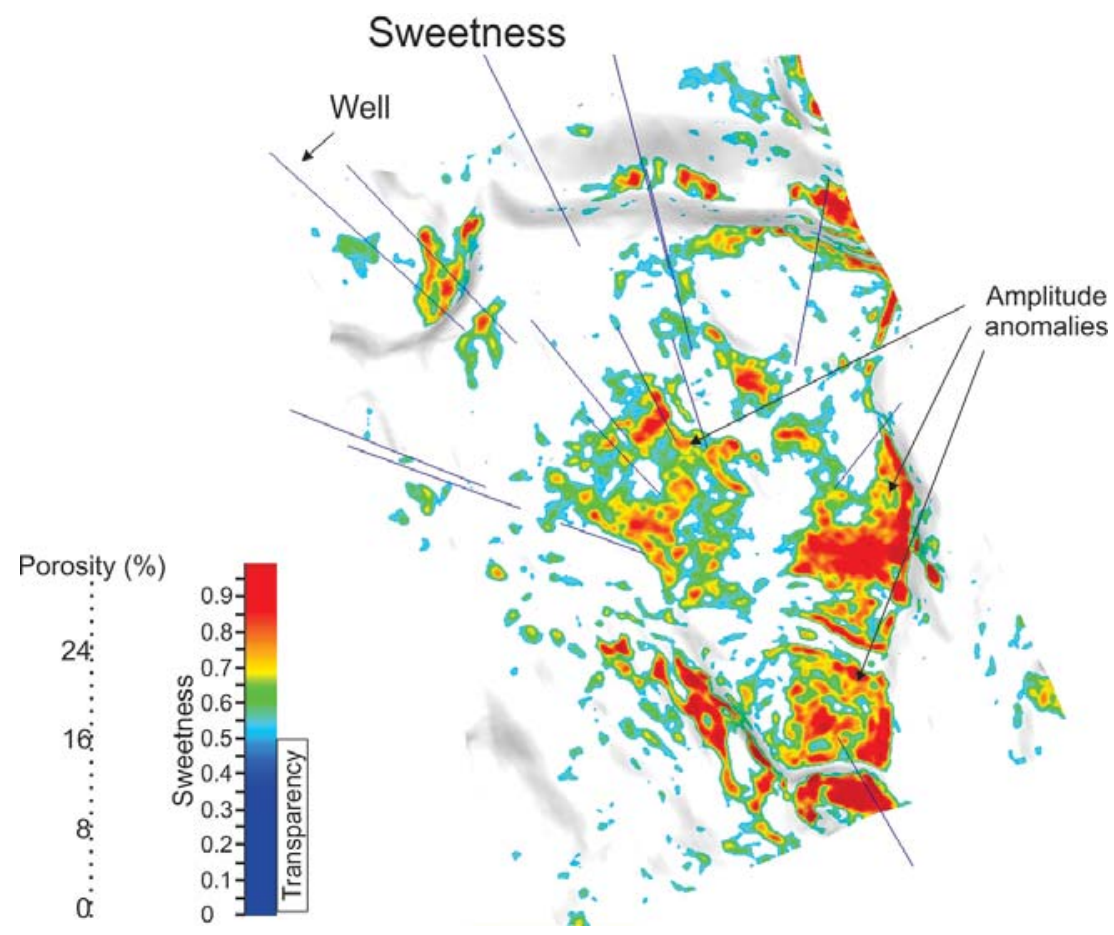

Figure 17 - Pseudo-porosity map of the reservoir R1 using the volumetric attribute Sweetness. In order to highlight the high porosity facies (>16\%), it was applied a cut-off in value of 0.5 . This map shows amplitude anomalies associated to porous rock in the study area and a direct association of the rock property which classifies this attribute as an effective tool to characterize this carbonate reservoir distribution.

\section{CONCLUSIONS}

The seismic attributes were effective in characterizing the porosity and density of the studied upper Albian carbonate reservoirs (R1 and R2). A linear correlation with R2 coefficient $>0.74$ was obtained among Maximum Negative Amplitude, Maximum Absolute Amplitude and Minimum Amplitude attributes and these physical properties of the rock; and $R^{2}>0.65$ for RMS Amplitude and Total Energy. 
These attribute maps were validated qualitatively with petrophysical maps and well logs analysis associated to structural context established in seismic interpretation. It shows the importance of a well-known geological review to support the mathematical relation presented in this paper. These attributes emphasized a central structural high that was highlighted in petrophysical maps because it shows high porosity ( $>20 \%$ ) and low density $\left(<2.35 \mathrm{~g} / \mathrm{cm}^{3}\right)$ delimited by faults to the Northeast, Southeast and Southwest.

In addition to the structural factor, the lateral change of carbonate facies was observed, mainly in the Northwest, where the reservoir rock shows high density $\left(>2.55 \mathrm{~g} / \mathrm{cm}^{3}\right)$ and low porosity $(<18 \%)$, not highlighted in the attribute maps.

Based on this analysis, it can be concluded that the Albian producing reservoirs (R1 and R2) in the study area are delimited by a structural-stratigraphic trap and the seismic attributes only highlight the high quality porous facies.

Besides the central structural high, the seismic attributes highlighted porous facies in reservoir levels in South and Southeast, what suggests the existence of other porous reservoir rock.

The seismic attributes showed their importance in the identification of the high quality facies of the reservoirs, as a tool of fast access and that could be a criterion for wells drilling and reservoir development strategies considering all geological settings.

\section{ACKNOWLEDGEMENTS}

The authors would like to thank the Landmark for providing the license of Decision Space software. Also, we wish to thank the ANP and Petrobras for providing the database. This research was developed in the Laboratory of Geology and Seismic Integration (LISG) in Center for Geosciences Applied to Petroleum UNESPetro, UNESP, Rio Claro, São Paulo, Brazil.

\section{REFERENCES}

BUENO JF, HONORIO BCZ, KURODA MC, VIDAL AC \& PEREIRA E. 2014. Structural and stratigraphic features delineation and facies seismic attributes and well log analysis applied to a Brazilian carbonate field. Interpretation, 2(1): SA83-SA92.

DIAS JL, SCARTON JC, ESTEVES FR, CARMINATTI M \& GUARDADO
LR. 1990. Aspectos da evolução tectono-sedimentar e a ocorrência de hidrocarbonetos na Bacia de Campos. In: GABAGLIA GPR \& MILANI EJ (Eds.). Origem e Evolução de Bacias Sedimentares, 2 ed., Rio de Janeiro, Brazil, 333-360.

ESTEVES FR, SPADINI AR \& SAITO M. 1987. A sedimentação alboturoniana (Formação Macaé) da Bacia de Campos. In: Simpósio de Geologia Regional RJ-ES, 1., Rio de Janeiro, Brazil. Anais... Sociedade Brasileira de Geologia, p. 27-42.

GUARDADO LR, GAMBOA LAP \& LUCCHESI CF. 1989. Petroleum Geology of the Campos Basin, Brazil, a Model for a Producing Atlantic Type Basin. In: EDWARDS JD \& SANTOGROSSI PA (Eds.). Divergent/Passive Margin Basin. Tulsa: AAPG Memoir, p. 3-79.

HORSCHUTZ PMC, FREITAS LCS, STANK CV, BARROSO AS \& CRUZ WM. 1992. The Linguado, Carapeba, Vermelho and Marimba giant oil field, Campos Basin, offshore Brazil. In: HALBOUTY MT (Ed.). Giant Oil Fields of the Decade 1978-1988. Tulsa: AAPG Memoir, p. 137-153.

NASCIMENTO LF. 2016. Modelo Geológico 3D de Reservatório Carbonático Albiano no Sudoeste da Bacia de Campos (RJ). Masters dissertation in Geosciences, Instituto de Geociências e Ciências Exatas, Universidade Estadual Paulista, Rio Claro, São Paulo, Brazil, 147 pp.

OKUBO J. 2014. Calcários Albianos de Campo Petrolífero na Bacia de Campos: Fácies, Diagênese e Modelo Deposicional. Masters dissertation in Regional Geology, Instituto de Geociências e Ciências Exatas, Universidade Estadual Paulista, Rio Claro, São Paulo, Brazil, $113 \mathrm{pp}$.

OKUBO J, LYKAWKA R, WARREN LV, FAVORETO J \& DIAS-BRITO D. 2015. Depositional, diagenetic and stratigraphic aspects of Macaé Group carbonates (Albian): example from an oilfield from Campos Basin. Brazilian Journal of Geology, 45(2): 243-258.

SPADINI AR. 1986. Oolitos: sua ocorrência na Formação Macaé, Bacia de Campos e sua importância como formadores de reservatórios de hidrocarbonetos. In: Congresso Brasileiro de Geologia, 34., Goiânia, Brazil. Anais... Sociedade Brasileira de Geologia, p. 1689-1700.

VINCENTELLI MGC, CONTRERAS SAC \& CHAVES MU. 2014. Geophysical Characterization of Albian Carbonates Reservoirs in Brazilian Basins: The Sweetness as a tool for carbonate reservoirs definition. Brazilian Journal of Geophysics, 32(4): 695-705.

WINTER, WR, JAHNERT RJ \& FRANÇA AB. 2007. Bacia de Campos. Boletim de Geociências da Petrobras, 15(2): 511-529.

Recebido em 18 janeiro, 2017 / Aceito em 26 junho, 2017

Received on January 18, 2017 / Accepted on June 26, 2017 